\title{
Neonatal Capsaicin Administration Impairs Postnatal Development of the Cardiac Chronotropy and Inotropy in Rats
}

\author{
J. KUNCOVÁ ${ }^{1,2}$ A. JIRKOVSKÁ ${ }^{3}$, J. ŠVÍGLEROVÁ ${ }^{1,2}$, M. MARKOVÁ ${ }^{1}$, D. MEIRELES ${ }^{1}$, \\ M. ČEDÍKOVÁ ${ }^{1,2}$ \\ ${ }^{1}$ Department of Physiology, Faculty of Medicine in Pilsen, Charles University, Pilsen, Czech \\ Republic, ${ }^{2}$ Biomedical Center, Faculty of Medicine in Pilsen, Charles University, Pilsen, Czech \\ Republic, ${ }^{3}$ Department of Biochemical Sciences, Faculty of Pharmacy, Charles University, Hradec \\ Králové, Czech Republic
}

Received March 27, 2016

Accepted November 8, 2016

\begin{abstract}
Summary
The present study evaluated the impact of neonatal administration of capsaicin (neurotoxin from red hot pepper used for sensory denervation) on postnatal development of the heart rate and ventricular contractility. In the rats subjected to capsaicin administration $(100 \mathrm{mg} / \mathrm{kg})$ on postnatal days 2 and 3 and their vehicle-treated controls at the ages of 10 to 90 days, function of the sympathetic innervation of the developing heart was characterized by evaluation of chronotropic responses to metipranolol and atropine, norepinephrine concentrations in the heart, and norepinephrine release from the heart atria. Sensory denervation was verified by determination of calcitonin generelated peptide levels in the heart. Direct cytotoxic effects of capsaicin were assessed on cultured neonatal cardiomyocytes. Capsaicin-treated rats displayed higher resting heart rates, lower atropine effect, but no difference in the effect of metipranolol. Norepinephrine tissue levels and release did not differ from controls. Contraction force of the right ventricular papillary muscle was lower till the age of 60 days. Significantly reduced viability of neonatal cardiomyocytes was demonstrated at capsaicin concentration $100 \mu \mathrm{mol} / \mathrm{l}$. Our study suggests that neonatal capsaicin treatment leads to impaired maturation of the developing cardiomyocytes. This effect cannot be attributed exclusively to sensory denervation of the rat heart since capsaicin acts also directly on the cardiac cells.
\end{abstract}

\section{Key words}

Capsaicin • Sensory denervation • Cytotoxicity • Postnatal development $\bullet$ Rat heart

\section{Corresponding author}

J. Kuncová, Department of Physiology, Biomedical Center, Faculty of Medicine in Pilsen, Charles University, alej Svobody 76, 32300 Plzeň, Czech Republic. E-mail: jitka.kuncova@lfp.cuni.cz

\section{Introduction}

Sensory innervation of the mammalian heart is represented by viscerosensitive neurons whose cell bodies were identified in the nodose and dorsal root ganglia C7 - T4 (Hopkins and Armour 1989). In addition to their afferent function, i.e. transmitting impulses from the cardiac mechano- and chemoreceptors, these neurons also release calcitonin gene-related peptide (CGRP), substance $\mathrm{P}$ and related neurokinins in the periphery, thereby contributing to the neuronal control of cardiac functions (Rubino and Burnstock 1996).

CGRP was discovered in 1982 by molecular cloning of the calcitonin gene (Amara et al. 1982) and since then, its cardiovascular distribution and effects have been extensively studied. In the rat heart, CGRP has been detected in the nerve fibers supplying atrial and ventricular cardiomyocytes, pericardium and endocardium. Nerve fibers releasing CGRP form a dense network also in the wall of the coronary arteries of various species including man (Franco-Cereceda et al. 1987). In addition, numerous synaptic contacts between sensory CGRP-positive fibers and intracardiac ganglionic neurons were detected in the guinea pig and mouse hearts (Hardwick et al. 1995, Li et al. 2014). 
CGRP has positive chronotropic and inotropic effects comparable to isoproterenol and exerts potent and long-lasting vasodilatation (Brain et al. 1985). It even might contribute to the regulation of basal coronary blood flow (Yaoita et al. 1994). Recently, it has attracted substantial research interest as a putative mediator of the ischemic preconditioning (Rana et al. 2015, Sun and Pan 2014).

The influence of the sympathetic innervation on the postnatal development of various aspects of the cardiac function has been extensively studied (Protas and Robinson 1999, Protas et al. 2003, Sviglerova et al. 2008). Also, the effect of chemical sympathectomy on CGRP-positive innervation of the cardiovascular system has been widely investigated (Aberdeen et al. 1992, Rubino et al. 1997a). In contrast, data concerning the action of sensory nerves on the postnatal development of the cardiac functions and sympathetic activity are scarce or missing (Rubino et al. 1997b, Kuncova et al. 2005).

The present study was undertaken to investigate the putative interactions between sensory innervation and postnatal development of the cardiac chronotropy and ventricular contractility. In addition, some markers of the sympathetic activity were determined in rats subjected to neonatal sensory denervation using capsaicin treatment. Capsaicin, the pungent alkaloid of hot red pepper, exerts multiple biological effects including cardioprotective, anti-lithogenic, anti-inflammatory, analgesic, and thermogenic actions (Srinivasan 2016). In the experimental practice, capsaicin is used to induce selective sensory denervation associated with $94 \%$ loss of type $\mathrm{C}$ afferent neurons in the sensory ganglia (Nagy et al. 1983, Lynn 1990).

\section{Materials and Methods}

\section{Animals}

All experiments were conducted in accordance with the European Directive for the Protection of Vertebrate Animals Used for Experimental and Other Scientific Purposes (86/609/EU), the relevant Guidelines of the Czech Ministry of Agriculture for Scientific Experimentation on Animals and were approved by the University Committee for Experiments on Laboratory Animals and Faculty of Pharmacy Animal Care Committee. Wistar rats of both sexes bred in our laboratory were used. Pregnant rats were housed individually with free access to food and water. After birth, litters were made up of 8-10 pups each. To achieve sensory denervation, rats received capsaicin $(100 \mathrm{mg} / \mathrm{kg}$, s.c.; Sigma Aldrich, Prague, Czech Republic) in two doses on postnatal days 2 and 3. Their controls were injected with the vehicle only (i.e. saline containing $10 \%$ of ethanol and $10 \%$ of Tween 80 ).

\section{Heart rate, effect of atropine and metipranolol}

The heart rate values were obtained from the conscious rats at the ages $10,20,30,40,60$, and 90 days $(n=8-10$ per age category for both control and capsaicintreated animals). Rats were placed in a chamber with electrodes in the floor that were connected to an electrocardiograph (EKG Seiva Praktik, Prague, Czech Republic). Animals were left to adapt for $20 \mathrm{~min}$ before the resting heart rate was measured three times in one-minute intervals. To estimate the tonic influence of the cardiac sympathetic innervation on the heart rate, the $\beta$-adrenergic receptor antagonist metipranolol (HoechstBiotika, Martin, Slovac Republic; $2 \mathrm{mg} / \mathrm{kg}$, s.c.) was administered subcutaneously after pretreatment with the muscarinic receptor blocker atropine (atropine sulphate, Sigma Aldrich, Prague, Czech Republic; $4 \mathrm{mg} / \mathrm{kg}$ of body weight). The effects of injected drugs reached maximum values within $5 \mathrm{~min}$ and were maintained for $>30 \mathrm{~min}$. The time interval between atropine and metipranolol administration was $20 \mathrm{~min}$. Antagonist-induced changes were calculated as the differences between pre-drug values and those observed $20 \mathrm{~min}$ after the drug administration. The values presented in the results represent means of these measurements.

Determination of CGRP and norepinephrine tissue concentrations

For quantitative determination of the cardiac CGRP and norepinephrine levels, rats at the ages of 10 , $20,40,60$ and 90 days were used ( $\mathrm{n}=6$ in each group). Rats were killed by cervical dislocation and their hearts were rapidly excised, rinsed with ice-cold saline, freed of connective tissue and fat and separated into left atria (LA) with the interatrial septum, right atria (RA), and free walls of both ventricles ( $R V$ and $L V$ ). Immediately after dissection, the tissues were frozen on the dry ice and weighed. CGRP was extracted from pulverized tissues by boiling in 10 volumes of $0.1 \mathrm{~mol} / \mathrm{l} \mathrm{HCl}$, rapid cooling on ice and homogenization. After centrifugation, the supernatants were neutralized and centrifuged again. The final supernatants were stored at $-70{ }^{\circ} \mathrm{C}$ until radioimmunoassay (RIA) for CGRP concentration measurements using commercial kits (Phoenix 
Pharmaceuticals, USA). Norepinephrine was extracted from the tissue samples by homogenization in 10 volumes of $0.1 \mathrm{~mol} / 1 \mathrm{HCl}$ and subsequent centrifugation. Supernatants were diluted 1:10 with distilled water and stored at $-70^{\circ} \mathrm{C}$ until RIA (IBL Hamburg, Germany).

\section{Norepinephrine release}

Control and capsaicin-treated rats at the age of 60 days were used. Both atria were dissected, sliced by McIllwain tissue chopper, pooled and transferred into $0.5 \mathrm{ml}$ perfusion chambers $(\mathrm{n}=6$ for both control and capsaicin-treated atria). Tissues were superfused at a rate of $0.15 \mathrm{ml} / \mathrm{min}$ with oxygenated $\left(95 \% \mathrm{O}_{2} / 5 \% \mathrm{CO}_{2}\right)$ Krebs-Henseleit (KH) solution of the following composition (in mmol/l): $\mathrm{NaCl} 113, \mathrm{NaHCO}_{3} 25, \mathrm{KCl}$ 4.75, $\mathrm{CaCl}_{2}$ 2.5, $\mathrm{MgSO}_{4}$ 1.19, glucose 11.1, $\mathrm{Na}_{2}$ EDTA 0.029 , ascorbic acid 0.289 , norepinephrine uptake blocker desipramine $10^{-4}$, and monoaminooxidase inhibitor pargyline $10^{-2}$. All perfusion experiments were performed at $37^{\circ} \mathrm{C}$ and superfusates were collected at $0{ }^{\circ} \mathrm{C}$. After a 30 min equilibration period, spontaneous (basal) release of norepinephrine was measured in fraction B1, i.e. in the course of perfusion by the $\mathrm{KH}$ solution containing $4.75 \mathrm{mmol} / \mathrm{l} \mathrm{KCl}$. Then, norepinephrine outflow was stimulated by depolarisation with a superfusion fluid containing $50 \mathrm{mmol} / \mathrm{l} \mathrm{KCl}$, in which the concentration of $\mathrm{NaCl}$ was reduced by $50 \mathrm{mmol} / \mathrm{l}$, and norepinephrine concentration was measured in fraction S1. After $\mathrm{S} 1$ collection, the same cycle was repeated, i.e. fractions B2 and S2 were acquired. In addition, the effect of tyramine $\left(10^{-5} \mathrm{~mol} / \mathrm{l}\right)$, a catecholamine releaser was tested $(n=6)$. Norepinephrine concentrations in the superfusates were determined using radioimmunoassay diagnostic kits (LDN, Germany).

\section{Beating rate of isolated right atria in vitro}

The right atria $(n=6-8$ per age category for both control and capsaicin-treated animals) were cut off and placed into an experimental chamber with oxygenated Tyrode solution $\left(32{ }^{\circ} \mathrm{C}\right)$ of following composition (in mmol/1): $\mathrm{NaCl} 137, \mathrm{KCl} 4.5, \mathrm{MgCl}_{2} 1, \mathrm{CaCl}_{2} 2$, glucose 10, Hepes 5; pH was adjusted to 7.4 with $\mathrm{NaOH}$. After stabilization period, the spontaneous beating frequencies were recorded and analyzed using the laboratory system Biopac (Biopac Systems, Inc., Goleta, California, USA).

\section{Contraction experiments}

The papillary muscles were dissected from the right ventricle ( $n=5-6$ per group) and placed into the experimental chamber with Tyrode solution, where they were attached to an isometric force transducer F30 (Hugo Sachs, March-Hugstetten, Germany). The preparation was perfused with $36{ }^{\circ} \mathrm{C}$ warm oxygenated solution at a constant flow rate $(6-10 \mathrm{ml} / \mathrm{min})$. After stabilization period $(>30 \mathrm{~min})$, the steady-state contractions were recorded (stimulation frequencies 3, 2, 1, 0.5, 0.3, 0.2 and $0.1 \mathrm{~Hz}$ ). The resting tension was taken as zero. Data were recorded using the data acquisition system DiSys (Medisoft International, Czech Republic). Contractions were measured in arbitrary units (a.u.).

\section{Cytotoxicity assay}

Neonatal ventricular cardiomyocytes (NVCMs) were isolated from 1- to 3-day-old Wistar rats using standard methods and cultured as previously described (Jirkovska-Vavrova et al. 2015). To visualize active mitochondria, the culture of spontaneously beating NVCMs was loaded $48 \mathrm{~h}$ after isolation with $3 \mu \mathrm{mol} / 1$ JC-1 probe (Molecular Probes, USA) for $15 \mathrm{~min}$ at $37^{\circ} \mathrm{C}$. After loading, the cells were incubated in ADS buffer complemented with $5 \mathrm{mmol} / 1$ glucose and $1 \mathrm{mmol} / \mathrm{l}$ $\mathrm{CaCl}_{2}$ with 3-300 $\mu \mathrm{mol} / 1$ capsaicin dissolved in DMSO (final concentration $0.1 \%$ ). The fluorescence was measured using Tecan Infinite plate reader (Tecan Group,

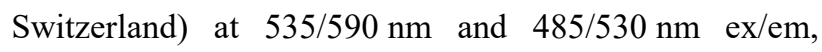
respectively, in the 30-min intervals for $6 \mathrm{~h}$.

A sample of the culture medium was taken from each well to assess lactate dehydrogenase (LDH) activity as an index of the plasma membrane damage and the changes in cellular morphology were assessed using an Eclipse TS100 inverted epifluorescence microscope (Nikon Corporation, Japan) and NIS-Elements AR 2.20 software (Laboratory Imaging, Czech Republic). The control wells were then treated with lysis buffer to measure the total cellular LDH level. The activity of LDH was assayed as described in Jirkovska-Vavrova et al. (2015) and the data were expressed as percent of total LDH.

\section{Data analysis}

Results are expressed as means \pm SEM. Normality of populations and homogeneity of variances were tested before analysis of variance (one-way ANOVA or Kruskall-Wallis test). Statistical differences were tested by post-hoc Fisher's Least Significant 
Difference test or Mann-Whitney $U$ test, where appropriate, using software package STATISTICA Cz, version 8 (StatSoft Inc., 2007, Prague, Czech Republic), OriginPro 8.5 (OriginLab Corporation, Northampton, MA, USA, 2011) or GraphPad Prism 6.00 for Windows (GraphPad Software, USA). The results were considered significantly different when $\mathrm{p}<0.05$.

\section{Results}

Heart rate, effect of atropine and metipranolol

In the control animals, the resting heart rate was high in the course of first three weeks after birth $\left(430 \pm 10 \mathrm{~min}^{-1}\right.$ at postnatal day 10$)$ and then declined to
$376 \pm 10 \mathrm{~min}^{-1}$ at the age of 90 days (Fig. 1A). Denervated animals displayed heart rates exceeding $410 \mathrm{~min}^{-1}$ till the end of experiments. From the day 40 after birth onward, heart rates of capsaicin-treated animals were significantly higher than those in the age matched controls $(p<0.05)$. The heart rate increasing effect of atropine was significantly smaller in the rats subjected to sensory denervation in the same time period (i.e. from day 40 onwards) (Fig. 1B). The effect of metipranolol after previous administration of atropine did not differ between the two groups at any time point studied (Fig. 1C). "Intrinsic" heart rate was significantly lower in capsaicintreated animals on postnatal days 20, 30, and 40 (Fig. 1D).
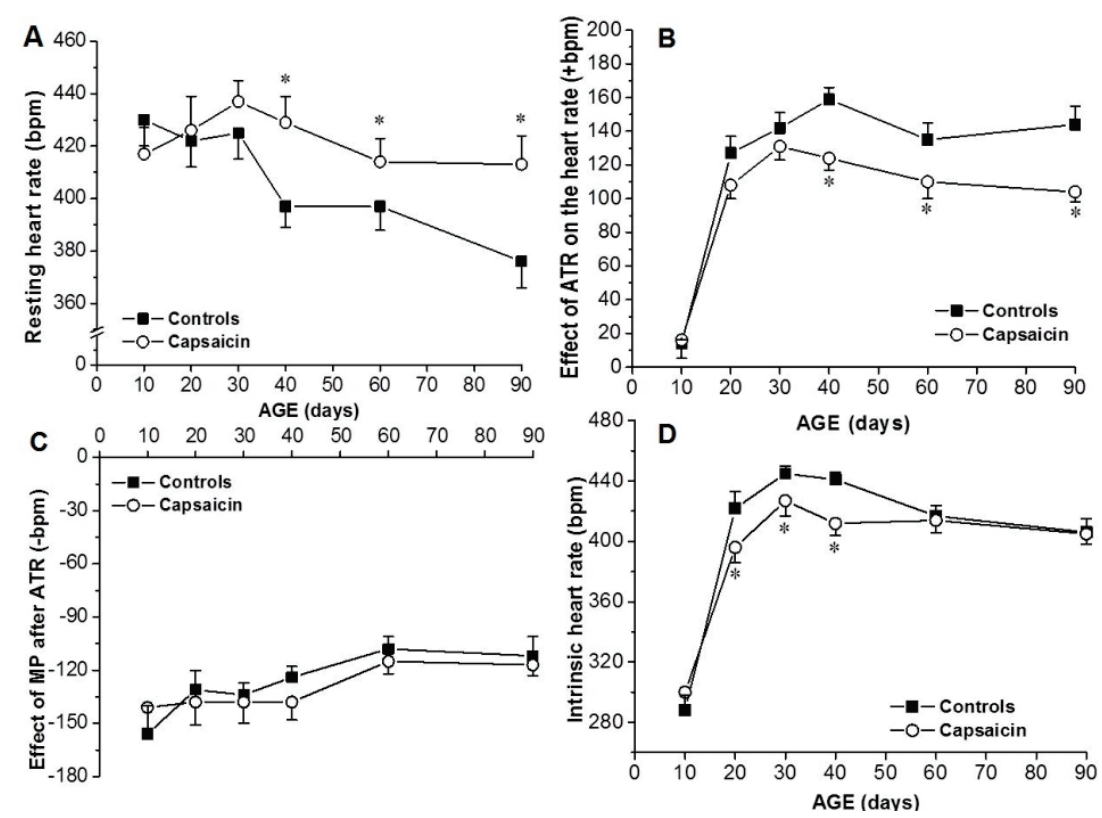

A

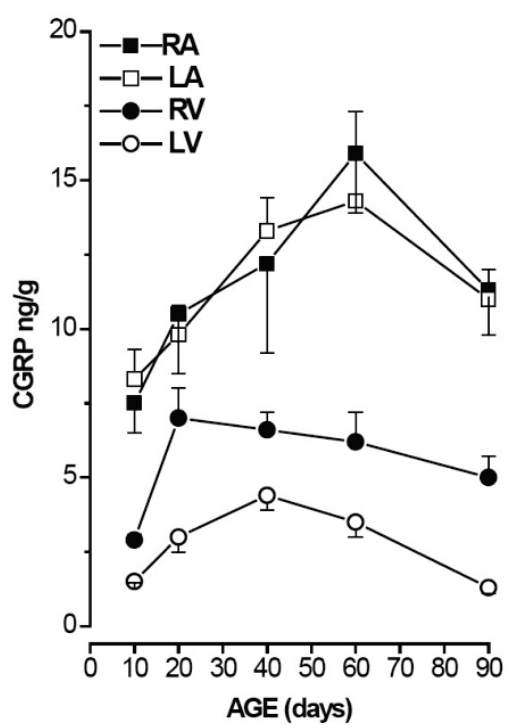

B

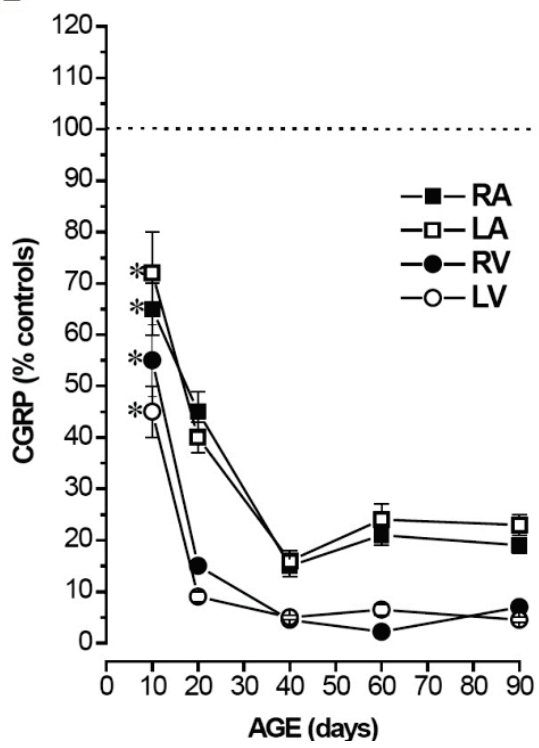

Fig. 1. Resting heart rate (A), effect of atropine on the resting heart rate (B), effect of metipranolol after atropine administration on the heart rate $(\mathbf{C})$, heart rate after atropine + metipranolol administration "intrinsic" heart rate (D) in the control and capsaicin treated rats. $* p<0.05$, compared to the respective control value.
Fig. 2. CGRP concentrations in the heart compartments (RA, LA - right and left atrium; RV, LV - free walls of the right and left ventricles) of control rats aged 10 to 90 days (A). CGRP concentrations in the heart compartments of capsaicin-treated rats aged 10 to 90 days expressed in \% of control values (B). $* p<0.05$, compared to the value at day 10 . 


\section{CGRP concentrations in the heart compartments}

The quality of sensory denervation after neonatal capsaicin administration was verified by determination of CGRP concentrations in both atria and ventricles (Fig. 2A,B). From the age of 40 days, CGRP levels in both ventricles did not exceed $10 \%$ of the control values and those in the atria represented $\sim 20 \%$ of vehicle treated controls.

\section{Norepinephrine concentrations in the heart compartments}

The absolute values of norepinephrine levels in control rats did not change significantly from the postnatal day 20 onwards. At the age of 10 days, norepinephrine concentrations in all heart compartments were significantly lower than in the remaining age categories (Fig. 3A). Concentrations of norepinephrine expressed in $\mathrm{ng} / \mathrm{g}$ tissue wet weight varied between $920 \pm 74,887 \pm 89,383 \pm 24$, and $284 \pm 29$ (at the age of 10 days) and $1589 \pm 139,1485 \pm 111,655 \pm 51$, and $541 \pm 38$ (at the age of 90 days) in the RA, LA, RV, and LV, respectively. Although there was a slight trend towards an increase in norepinephrine concentrations in the heart compartments of denervated rats from the day 40 after birth, none of the relative increments reached statistical significance. In the capsaicin-treated rats, norepinephrine concentrations reached maximally $135 \%$ of the respective control values in the LA at the age of 60 days (Fig. 3B).

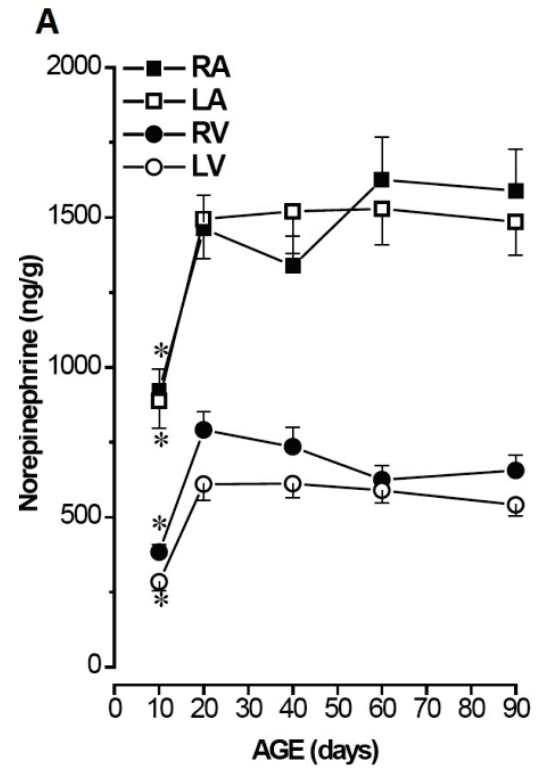

Norepinephrine release

Basal release of norepinephrine from the sliced atria did not exceed $0.3 \mathrm{ng} / \mathrm{g} / \mathrm{min}$. Norepinephrine release was successfully stimulated by $\mathrm{KCl}$-induced depolarization in both control $(\mathrm{S} 1=2.2 \pm 0.3 ; \mathrm{S} 2=1.9 \pm 0.2$ $\mathrm{ng} / \mathrm{g} / \mathrm{min}$ ) and denervated preparations ( $\mathrm{S} 1=2.4 \pm 0.4$; $\mathrm{S} 2=2.2 \pm 0.2 \mathrm{ng} / \mathrm{g} / \mathrm{min}$ ). Tyramine further increased norepinephrine release to maximally $4.7 \pm 0.3 \mathrm{ng} / \mathrm{g} / \mathrm{min}$ ( $\mathrm{S} 1$ in controls). No differences were noted between control and denervated samples.

\section{Beating rate of isolated right atria in vitro}

Spontaneous beating frequencies of the isolated right atria ranged from $135 \pm 11 \mathrm{~min}^{-1}$ at the age of 10 days to $161 \pm 6 \mathrm{~min}^{-1}$ at the age of 90 days and they did not differ significantly among the groups. Beating rates in capsaicin-treated rats were significantly lower compared
Fig. 3. Norepinephrine concentrations in the heart compartments (RA, LA - right and left atrium; RV, LV - free walls of the right and left ventricles) of control rats aged 10 to 90 days (A). Norepinephrine concentrations in the heart compartments of capsaicintreated rats aged 10 to 90 days expressed in $\%$ of control values (B). * $p<0.05$, compared to values in all remaining age categories. to age-matched controls from day 10 after birth $\left(102 \pm 9 \mathrm{~min}^{-1}\right)$ till the age of 40 days $\left(130 \pm 8 \mathrm{~min}^{-1}\right.$ vs. $157 \pm 5 \mathrm{~min}^{-1}$ ) and then they were comparable to the control values.

\section{Contraction experiments}

Sensory denervation significantly decreased the contraction force (CF) of the papillary muscles in 20-, 40and 60-day-old rats at all stimulation frequencies tested. $\mathrm{CF}$ at stimulation frequency $2 \mathrm{~Hz}$ was $41.8 \pm 5.2$ a.u. and $5.4 \pm 0.6$ a.u. (20 days), $52 \pm 4.1$ a.u. and $13 \pm 2.2$ a.u. (40 days), $62 \pm 3$ a.u. and $20.4 \pm 3.9$ a.u. in the intact and denervated rats, respectively (Fig. 4). At day 90, this reduction disappeared and $\mathrm{CF}$ was comparable in both experimental groups at all stimulation frequencies tested (CF at $2 \mathrm{~Hz} 73 \pm 7.5$ a.u. in the control group and $61 \pm 8.4$ a.u. in the denervated one). 


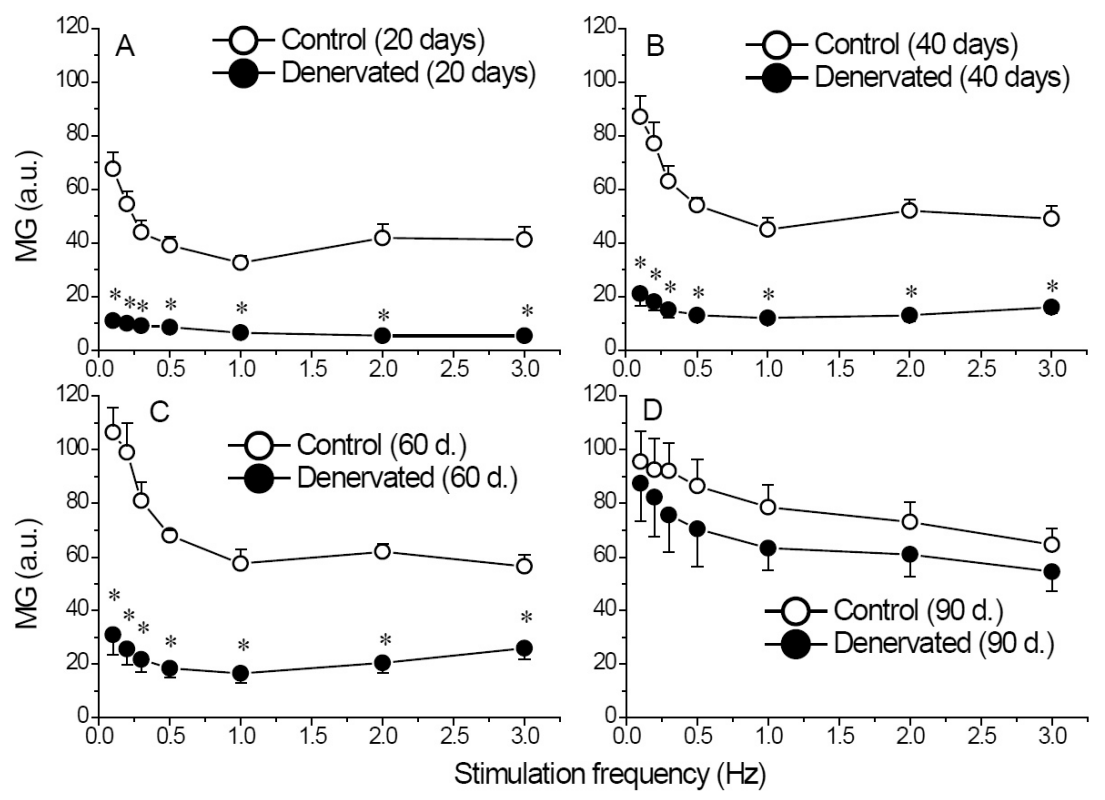

Fig. 4. The dependence of contraction force (CF) on stimulation frequency in the control and denervated RV papillary muscles of rats aged 20 (A), 40 (B), 60 (C) and 90 (D) days. Open circles - control rats, filled circles - denervated rats. * significantly different from age-matched control group $(p<0.05)$.

Toxicity of capsaicin to neonatal rat cardiomyocytes

Capsaicin had profound toxic effect on the NVCMs at $300 \mu m o l / 1$. Almost all cells lost their mitochondrial membrane potential $\left(\Delta \Psi_{\mathrm{m}}\right)$ in $30 \mathrm{~min}$ (Fig. 5) and at the end of experiment, almost all cells had their plasma membrane permeabilized (Fig. 5). Statistically significant mitochondrial damage was also seen after $6 \mathrm{~h}$ in samples incubated with $100 \mu \mathrm{mol} / 1$ capsaicin and at this concentration, a marked vacuolization of the cytoplasm was seen. The mitochondrial damage was notable also in samples treated with 10 and $30 \mu \mathrm{mol} / 1$, where clear rise of green fluorescence was seen after the 6-h treatment, and a rising trend is seen in the amount of $\mathrm{LDH}$ released, although these changes were not statistically significant. Notably, samples treated with the lower concentrations of capsaicin (3 and $10 \mu \mathrm{mol} / \mathrm{l}$ ) showed raised beating frequency of the neonatal cardiomyocytes after the 6-h incubation period.
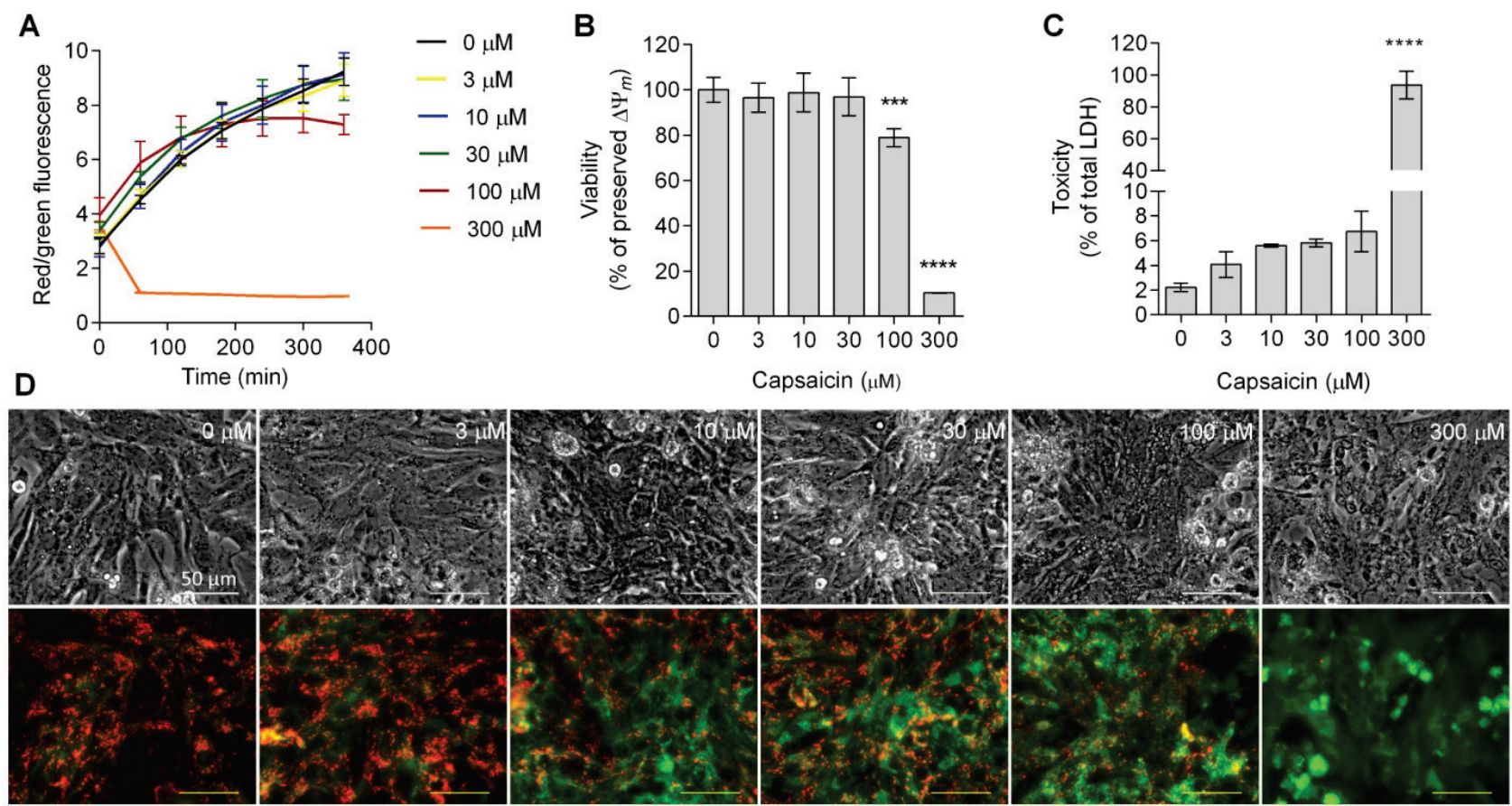

Fig. 5. Toxicity of capsaicin on the isolated neonatal rat cardiomyocytes. Mitochondrial membrane potential changes in time measured as the ratio of red and green fluorescence of the JC-1 probe $(\mathbf{A})$, the ratio after the $6 \mathrm{~h}$ of incubation (B), toxicity (lactate dehydrogenase release - $L D H)(\mathbf{C})$ and the micrographs showing the morphology (in brightfield upper panels) and mitochondrial membrane potential (lower panels) of cardiomyocytes (D) after $6 \mathrm{~h}$ incubation with capsaicin. * significantly different from control $(* * * \mathrm{p}<0.001, * * * * \mathrm{p}<0.0001)$. 


\section{Discussion}

The results of the present study show that neonatal capsaicin administration leads to long-lasting changes in the heart rate and cardiac contractility in the developing rat. Since capsaicin has been repeatedly reported as neurotoxin inducing selective sensory denervation acting nearly exclusively on the type $C$ nerve fibers (Jancso et al. 1977), it is tempting to speculate that the function of sensory innervation of the cardiovascular system during postnatal development is essential for normal maturation of the cardiac functions.

The cross-talk between the autonomic innervation of the heart and developing cardiomyocytes has been suggested on the basis of experimental data documenting long-term control of cardiomyocyte contractility by the sympathetic neurons. Expression of proteins related to calcium handling seems to be controlled by norepinephrine or neuropeptide Y (or both) released from the sympathetic nerve endings (Ogawa et al. 1992, Protas and Robinson 1999, Protas et al. 2003, Sviglerova et al. 2008).

In addition, neonatal chemical sympathectomy by guanethidine leads to a selective increase in CGRP expression in several tissues including heart suggesting mutual interactions between sensory and sympathetic nerves that might compete for the same neurotrophic factors released from the innervated tissues, namely nerve growth factor (Aberdeen et al. 1990, Supowit et al. 2005). In addition, sympathetic denervation in newborn rat is associated with a decreased inotropic responsiveness to CGRP and hypersensitive response to norepinephrine in adulthood (Rubino et al. 1996).

In this study, CGRP concentrations after neonatal capsaicin administration were low in all heart compartments till the end of experiments documenting successful sensory denervation. At the adult age (i.e. 90 days), heart rate of capsaicin treated animals was higher than in controls; however, this difference could not be attributed to the sympathetic excitation, since the effect of non-selective $\beta$-adrenergic receptor antagonist after previous muscarinic receptor blockade was not different between the two groups. Norepinephrine concentrations did not differ between control and denervated hearts at any of age categories studied and both depolarization-evoked and norepinephrine transporter-mediated releases of norepinephrine from the heart atria were comparable in both groups. All these findings infer that neonatal sensory denervation does not substantially affect the postnatal development of the sympathetic nerves supplying the heart. Unimpaired responsiveness of the atria subjected to neonatal sensory denervation to isoprenaline and norepinephrine has been documented in rats at the age of 14 weeks (Rubino et al. 1996). Taken together, the impact of sensory denervation on the sympathetic neurotransmission does not parallel the inversed situation, i.e. sensory hyperinnervation after neonatal sympathectomy.

The impaired ventricular contractility (ages 20-60 days) and decreased spontaneous beating rate of the right atria (10-40 days) in the course of postnatal development after neonatal sensory denervation are novel findings that might be related to the trophic effects of afferent nerves on the maturation of cardiac functions. Indeed, CGRP-mediated support of various myocardial functions has been documented to date: several studies have reported that CGRP in the cardiac afferent nerve fibers is the compound responsible for the myocardial protection provided by ischemic preconditioning, heat stress or progression of the adriamycin-induced cardiomyopathy (Zhou et al. 1999, Song et al. 1999, Katona et al. 2004). In addition, direct trophic effects of CGRP on the endothelial cells in vivo and myoblasts in vitro have been demonstrated (Noble et al. 1993, Mapp et al. 2012). Chronic CGRP receptor stimulation also accelerated maturation of excitation-contraction coupling in the cultured myoblasts isolated from newborn mice (Avila et al. 2007). Thus, the missing trophic effect of the sensory nerves in the course of postnatal development could be at least partly responsible for the impaired maturation of the cardiac chronotropy and inotropy documented in the present study.

It should be noted that TRPV1 (vanilloid) receptors mediating toxic effects of capsaicin (Caterina et al. 1997) are not present exclusively on the membranes of sensory nerve endings. A variety of non-neuronal cells express these receptors, including epithelial cells of the urinary and gastrointestinal tracts, lung, prostate, and human neutrophils and mast cells (Lazzeri et al. 2004, Stander et al. 2004, Seki et al. 2006, Saunders et al. 2007). Interestingly, transient localization of TRPV1 receptors has been documented also in the rat cardiomyocytes in the course of pre- and postnatal development from embryonic day 14 to postnatal day 30 (Dvorakova and Kummer 2001). Thus, we have performed experiments testing direct cytotoxic effects of capsaicin on cultured neonatal cardiomyocytes. Capsaicin concentrations used ranged between 3 and $300 \mu \mathrm{mol} / \mathrm{l}$, 
i.e. those that could be reached in vivo after subcutaneous administration of the drug (Zhang et al. 2010) and those widely used in experimental practice (Skrzypski et al. 2014). Although capsaicin did not significantly affect cardiomyocyte viability at concentrations up to $100 \mu \mathrm{mol} / 1$, cardiomyocytes treated with lower toxin concentrations (i.e. 3 and $10 \mu \mathrm{mol} / \mathrm{l}$ ) displayed raised beating frequency after 6-h incubation period, suggesting some direct effect of the toxin even at lower doses. In an experimental cytotoxic study, capsaicin in concentration of $50 \mu \mathrm{mol} / 1$ caused decrease in mitochondrial membrane potential, increase in cytochrome c release and reactive oxygen species generation in neuroendocrine tumor cells. These effects were only partly inhibited by TRPV1 receptor antagonist implying that TRPV1-independent mechanisms participate in capsaicin-induced cell death (Skrzypski et al. 2014). Thus, the direct toxic effect of capsaicin on neonatal cardiomyocytes could contribute to its long-lasting effects on the heart functions.

\section{Limitations}

This study was not focused on the potential impact of sensory denervation on the parasympathetic neurotransmission in the rat heart. A single study reported no effect of neonatal capsaicin administration on the negative chronotropic responses to pilocarpine and carbachol in isolated rat heart atria (Gasparetti et al. 2002). However, the question of selectivity of capsaicin to destroy only unmyelinated afferent neurons has been recently raised by Browning et al. (2013). Their data indicated that perivagal application of capsaicin induced degeneration of the dorsal motor nucleus of the vagus nerve and decreased vagal motor responses. Our finding of diminished effect of atropine on the heart rate seems to support this hypothesis.

\section{Conclusion}

Our study suggests that neonatal capsaicin treatment causes long-lasting sensory denervation of the rat heart resulting in the impaired maturation of the developing cardiomyocytes. However, this effect cannot be attributed exclusively to missing sensory innervation, since the possibility that capsaicin acts directly on the cardiac cells and/or the parasympathetic neurons supplying the heart cannot be ruled out and remains to be further elucidated.

\section{Conflict of Interest}

There is no conflict of interest.

\section{Acknowledgements}

This study was supported by the National Sustainability Program I (NPU I) Nr. LO1503 provided by the Ministry of Education Youth and Sports of the Czech Republic, the Charles University Research Fund (Nr. P36), and the Specific Student Research Project Nr. 260281/2016 of the Charles University, Prague.

\section{References}

ABERDEEN J, CORR L, MILNER P, LINCOLN J, BURNSTOCK G: Marked increases in calcitonin gene-related peptide-containing nerves in the developing rat following long-term sympathectomy with guanethidine. Neuroscience 35: 175-184, 1990.

ABERDEEN J, MILNER P, LINCOLN J, BURNSTOCK G: Guanethidine sympathectomy of mature rats leads to increases in calcitonin gene-related peptide and vasoactive intestinal polypeptide-containing nerves. Neuroscience 47: 453-461, 1992.

AMARA SG, JONAS V, ROSENFELD MG, ONG ES, EVANS RM: Alternative RNA processing in calcitonin gene expression generates mRNAs encoding different polypeptide products. Nature 298: 240-244, 1982.

AVILA G, AGUILAR CI, RAMOS-MONDRAGÓN R: Sustained CGRP1 receptor stimulation modulates development of EC coupling by cAMP/PKA signalling pathway in mouse skeletal myotubes. J Physiol 584: 47-57, 2007.

BRAIN SD, WILLIAMS TJ, TIPPINS JR, MORRIS HR, MACINTYRE I: Calcitonin gene-related peptide is a potent vasodilator. Nature 313: 54-56, 1985.

BROWNING KN, BABIC T, HOLMES GM, SWARTZ E, TRAVALGI RA: A critical re-evaluation of the specificity of action of perivagal capsaicin. J Physiol 591: 1563-1580, 2013.

CATERINA MJ, SCHUMACHER MA, TOMINAGA M, ROSEN TA, LEVINE JD, JULIUS D: The capsaicin receptor: a heat-activated ion channel in the pain pathway. Nature 389: 816-824, 1997. 
DVORAKOVA M, KUMMER W: Transient expression of vanilloid receptor subtype 1 in rat cardiomyocytes during development. Histochem Cell Biol 116: 223-225, 2001.

FRANCO-CERECEDA A, HENKE H, LUNDBERG JM, PETERMANN JB, HÖKFELT T, FISCHER JA: Calcitonin gene-related peptide (CGRP) in capsaicin-sensitive substance P-immunoreactive sensory neurons in animals and man: distribution and release by capsaicin. Peptides 8: 399-410, 1987.

GASPARETTI AL, HYSLOP S, COSTA SK, PRIVIERO FB, DE NUCCI G, ANTUNES E, ZANESCO A: Chronotropic response of beta-adrenergic-, muscarinic-, and calcitonin gene-related peptide-receptor agonists in right atria from neonatal capsaicin-treated rats. Neurosci Lett 325: 147-150, 2002.

HARDWICK JC, MAWE GM, PARSONS RL: Evidence for afferent fiber innervation of parasympathetic neurons of the guinea-pig cardiac ganglion. J Auton Nerv Syst 53: 166-174, 1995.

HOPKINS DA, ARMOUR JA: Ganglionic distribution of afferent neurons innervating the canine heart and physiologically identified cardiopulmonary nerves. J Auton Nerv Syst 26: 213-222, 1989.

JANCSÓ G, KIRALY E, JANCSÓ-GÁBOR A: Pharmacologically induced selective degeneration of chemosensitive primary sensory neurones. Nature 270: 741-743, 1977.

JIRKOVSKÁ-VÁVROVÁ A, ROH J, LENČOVÁ-POPELOVÁ O, JIRKOVSKÝ E, HRUŠKOVÁ K, POTU゚ČKOVÁMACKOVÁ E, JANSOVÁ H, HAŠKOVÁ P, MARTINKOVÁ P, EISNER T, KRATOCHVÍL M, ŠŮS J, MACHÁČEK M, VOSTATKOVÁ-TICHOTOVÁ L, GERŠL V, KALINOWSKI DS, MULLER MT, RICHARDSON DR, VÁVROVÁ K, ŠTĚRBA M, ŠIMU゚NEK T: Synthesis and analysis of novel analogues of dexrazoxane and its open-ring hydrolysis product for protection against anthracycline cardiotoxicity in vitro and in vivo. Toxicol Res 4: 1098-1114, 2015.

KATONA M, BOROS K, SÁNTHA P, FERDINANDY P, DUX M, JANCSÓ G: Selective sensory denervation by capsaicin aggravates adriamycin-induced cardiomyopathy in rats. Naunyn Schmiedebergs Arch Pharmacol 370: 436-443, 2004.

KUNCOVÁ J, FAITOVÁ Š, CAPOUCH J, GRUNDMANOVÁ M, MUDRA J, ŠVÍGLEROVÁ J, SLAVÍKOVÁ J: Long-term effects of guanethidine and capsaicin on the sympathetic innervation of the rat heart and aorta. In: Advances in Recent Cardiovascular Research. Monduzzi Editore S.p.A. - MEDIMOND Inc., Bologna, Italy, 2005, pp 53-57.

LAZZERI M, VANNUCCHI MG, ZARDO C, SPINELLI M, BENEFORTI P, TURINI D, FAUSSONE-PELLEGRINI MS: Immunohistochemical evidence of vanilloid receptor 1 in normal human urinary bladder. Eur Urol 46: 792-798, 2004.

LI L, HATCHER JT, HOOVER DB, GU H, WURSTER RD, CHENG ZJ: Distribution and morphology of calcitonin gene-related peptide and substance P immunoreactive axons in the whole-mount atria of mice. Auton Neurosci 181: 37-48, 2014.

LYNN B: Capsaicin: actions on nociceptive C-fibres and therapeutic potential. Pain 41: 61-69, 1990.

MAPP PI, MCWILLIAMS DF, TURLEY MJ, HARGIN E, WALSH DA: A role for the sensory neuropeptide calcitonin gene-related peptide in endothelial cell proliferation in vivo. Br J Pharmacol 166: 1261-1271, 2012.

NAGY JI, IVERSEN LL, GOEDERT M, CHAPMAN D, HUNT SP: Dose-dependent effects of capsaicin on primary sensory neurons in the neonatal rat. $J$ Neurosci 3: 399-406, 1983.

NOBLE BS, MCMILLAN DN, MALTIN CA: Calcitonin gene related peptide stimulates differentiation of neonatal rat myogenic cultures. Growth Regul 3: 245-248, 1993.

OGAWA S, BARNETT JV, SEN L, GALPER JB, SMITH TW, MARSH JD: Direct contact between sympathetic neurons and rat cardiac myocytes in vitro increases expression of functional calcium channels. J Clin Invest $\mathbf{8 9}$ : 1085-1093, 1992.

PROTAS L, ROBINSON RB: Neuropeptide Y contributes to innervation-dependent increase in $\mathrm{I}(\mathrm{Ca}, \mathrm{L})$ via ventricular Y2 receptors. Am J Physiol 277: H940-H946, 1999.

PROTAS L, BARBUTI A, QU J, RYBIN VO, PALMITER RD, STEINBERG SF, ROBINSON RB: Neuropeptide Y is an essential in vivo developmental regulator of cardiac ICa,L. Circ Res 93: 972-979, 2003.

RANA A, GOYAL N, AHLAWAT A, JAMWAL S, REDDY BV, SHARMA S: Mechanisms involved in attenuated cardio-protective role of ischemic preconditioning in metabolic disorders. Perfusion 30: 94-105, 2015. 
RUBINO A, BURNSTOCK G: Capsaicin-sensitive sensory-motor neurotransmission in the peripheral control of cardiovascular function. Cardiovasc Res 31: 467-479, 1996.

RUBINO A, RALEVIC V, BURNSTOCK G: Calcitonin gene-related peptide (CGRP)-evoked inotropism during hyper- and hypo-sensory-motor innervation in rat atria. J Auton Pharmacol 17: 121-127, 1997a.

RUBINO A, RALEVIC V, BURNSTOCK G: Sympathetic neurotransmission in isolated rat atria after sensory-motor denervation by neonatal treatment with capsaicin. J Pharmacol Exp Ther 282: 671-675, 1997b.

SABBAGH S, HENRY SALZMAN MM, KLONER RA, SIMKHOVICH BZ, REZKALLA SH: Remote ischemic preconditioning for coronary artery bypass graft operations. Ann Thorac Surg 96: 727-736, 1989.

SAUNDERS CI, KUNDE DA, CRAWFORD A, GERAGHTY DP: Expression of transient receptor potential vanilloid 1 (TRPV1) and 2 (TRPV2) in human peripheral blood. Mol Immunol 44: 1429-1435, 2007.

SEKI N, SHIRASAKI H, KIKUCHI M, SAKAMOTO T, WATANABE N, HIMI T: Expression and localization of TRPV1 in human nasal mucosa. Rhinology 44: 128-134, 2006.

SKRZYPSKI M, SASSEK M, ABDELMESSIH S, MERGLER S, GRÖTZINGER C, METZKE D, WOJCIECHOWICZ T, NOWAK KW, STROWSKI MZ: Capsaicin induces cytotoxicity in pancreatic neuroendocrine tumor cells via mitochondrial action. Cell Signal 26: 41-48, 2014.

SOBANSKI P, KRAJNIK M, SHAQURA M, BLOCH-BOGUSLAWSKA E, SCHÄFER M, MOUSA SA: The presence of mu-, delta-, and kappa-opioid receptors in human heart tissue. Heart Vessels 29: 855-863, 2014.

SONG QJ, LI YJ, DENG HW: Improvement of preservation with cardioplegia induced by heat stress is mediated by calcitonin gene-related peptide. Regul Pept 79: 141-145, 1999.

SRINIVASAN K: Biological activities of red pepper (Capsicum annuum) and its pungent principle capsaicin: a review. Crit Rev Food Sci Nutr 56: 1488-1500, 2016.

STÄNDER S, MOORMANN C, SCHUMACHER M, BUDDENKOTTE J, ARTUC M, SHPACOVITCH V, BRZOSKA T, LIPPERT U, HENZ BM, LUGER TA, METZE D, STEINHOFF M: Expression of vanilloid receptor subtype 1 in cutaneous sensory nerve fibers, mast cells, and epithelial cells of appendage structures. Exp Dermatol 13: 129-139, 2004.

SUN XJ, PAN SS: Role of calcitonin gene-related peptide in cardioprotection of short-term and long-term exercise preconditioning. J Cardiovasc Pharmacol 64: 53-59, 2014.

SUPOWIT SC, ETHRIDGE RT, ZHAO H, KATKI KA, DIPETTE DJ: Calcitonin gene-related peptide and substance P contribute to reduced blood pressure in sympathectomized rats. Am J Physiol Heart Circ Physiol 289: 1169-1175, 2005.

SVIGLEROVA J, KUNCOVA J, NALOS L, SLAVIKOVA J, STENGL M: Depressed cardiac contractility and its postnatal development in rats after chemical sympathectomy. Physiol Res 57: 507-515, 2008.

VAVROVA A, JANSOVA H, MACKOVA E, MACHACEK M, HASKOVA P, TICHOTOVA L, STERBA M, SIMUNEK T: Catalytic inhibitors of topoisomerase II differently modulate the toxicity of anthracyclines in cardiac and cancer cells. PLoS One 8: e76676, 2013.

YAOITA H, SATO E, KAWAGUCHI M, SAITO T, MAEHARA K, MARUYMA Y: Nonadrenergic noncholinergic nerves regulate basal coronary flow via release of capsaicin-sensitive neuropeptides in the rat heart. Circ Res 75: 780-788, 1994.

ZHANG Q, HU J, SHENG L, LI Y: Simultaneous quantification of capsaicin and dihydrocapsaicin in rat plasma using HPLC coupled with tandem mass spectrometry. J Chromatogr B Analyt Technol Biomed Life Sci 878: 2292-2297, 2010.

ZHOU FW, LI YJ, LU R, DENG HW: Protection of calcitonin gene-related peptide-mediated preconditioning against coronary endothelial dysfunction induced by reperfusion in the isolated rat heart. Life Sci 64: 1091-1097, 1999. 